F. Diniz ${ }^{\text {a) }}$, T. Sequeira ${ }^{\text {a) }}$

a) University of Trás-os-Montes and Alto Douro

\title{
PORTRAIT OF PORTUGAL'S NUT III REGIONS IN PRODUCTIVE LOCATION CLUSTERS
}

The purpose of this article is to piece together a picture of Portuguese regions at the end of the first decade of the twenty-first century. In particular, the authors tried to group NUT III regions according to the location of productive activities bearing in mind employment and other economic and social indicators, namely productivity and purchasing power, as well as competitiveness and environmental quality indicators. Using

${ }^{1}$ C Diniz F., Sequeira T. Text. 2015. 
clusters, it was possible to obtain a map of Portugal containing 6 cluster typologies. Clearly, at one end of these typologies are the regions where tertiary activities are predominant and where there is more purchasing power, productivity and competitiveness, causing, however, more damages to the environment, whereas at the other end are the rural less competitive regions with a lower purchasing power but environmentally more attractive. In between, there are other situations which are also looked into.

Keywords: Productive location, development, territorial cohesion

\section{Framework}

As a production grows more specialised, social character of production becomes more pronounced. Scientific and technological progress and larger scales of production are the most important factors in increased specialisation. Specialisation is characteristic of all branches of material production and of the non-productive sphere being especially advanced in the industry.

Productive specialization has always been at the heart of economic and regional development studies; recently, regional science literature has been providing some very good examples of it. It is the case of Akgüngör and Falcioğlu [1], who addressed the question of the relationship between Turkey's transforming industry regional specialization patterns and European integration; Michaels [2], who elaborated on the consequences of a long-term resources-based specialization; and Ezcurra et al [3], who, based on the information provided by various methodological instruments, wrote on regional integration in the E.U., examining the productive specialization in European Union's regions over the period between 1977 and 1999. The results obtained reveal a process of convergence in regional productive structures during the twenty-two year period considered.

As regards regional integration and industrial location, Traistaru and Iara [4] developed research based on Central and Eastern Europe countries within a project financed by E.U. Phare Program. The authors examine productive specialization in European Union regions over the period from 1977 to 1999 , using the information provided by various methodological instruments. The results of their study point to a process of convergence in regional productive structures during the same period.

In Portugal, Diniz and Sequeira [5] analysed how the specialization of Portuguese productive structures has evolved between 1995 and 2004, using specialization indicators, namely location quotient estimation, to assess both the relative degree of concentration of a given activity in a certain area and the specialization coefficient that helps characterize a region's economy according to its degree of specialization.
Desrochers [6] points out some shortcomings of traditional approaches to the study of "knowledge spillovers" and suggests an alternative based on how knowledge is actually created and exchanged by individuals. Evidence is drawn from the history of technology, from some Baltimore research-related activity cases conducted at John Hopkins University and from a survey of Southern Quebec inventors, stressing the fact that regional specialization has long been thought of as both the logical outcome of market competition and the best geographical setting for innovation.

Marelli [7] deals with the differentiated employment structures of the European regions, their evolution over time and their implications for economic growth. The analysis focuses on the distribution of employment between the main productive sectors over the period 19831997 in 145 regions of the EU. Some clusters of regions which are structurally similar are identified. Finally, in order to show the importance of the economic structure for long-run growth, the productive structures are related to convergence in per-capita incomes.

Goschin et al. [8] refer the economic specialisation of the regions and the spatial concentration of the economic activities that are reflecting the same reality from two different perspectives. Their research is an attempt to capture the main patterns and the evolution of regional specialisation and sectoral concentration in the Romanian economy for selected years during the 1996-2007 period, on the basis of the Gross Value Added and employment data, by branch and by region. They employed standard statistical measures of specialisation and concentration, combined with methods envisaging the amplitude and the speed of structural changes so as to highlight the various sides of these two complex phenomena

The concept of cluster was popularised by Michael Porter in the 1990s. His approach clearly derives from Marshall's work on agglomeration of economic activities. It is very broad, and it may include different perspectives since it is often used to designate industrial districts, innovative milieu, innovation systems, networks, value chain, growth poles, etc. That is to say, the concept of cluster is somewhat fuzzy and often used to embrace all rel- 
evant mechanisms underlying regional development and location or agglomeration theories [9].

However, when compared to other territorial innovation models, the cluster approach emphasises market and competition above networking and social interaction as success factors for innovation in clusters. Regional dimensions of innovation processes are only considered in a limited way. Regional innovation systems and learning regions (that are analysed in the following chapter) present a different approach, as they derive from an evolutionist perspective of economic development and institutional coordination [10]. Off all the concepts described in the previous sections, clusters present the most prominent example of how a concept can rapidly evolve and become dominant in academic research and policy-making, especially when compared to previous models that failed to have a significant impact on policy design and implementation. This occurred because clusters were able to fill the gap between theory and practice, becoming the most applied concept of regional development and agglomeration $[11,12]$.

Cooperation and competition (coopetition) are two forces that positively collide within clusters and are both fundamental for clusters to be competitive. Increased cooperation may derive from the strategic interdependence of clustered firms, as well as from the fact that there are simply more activities in which geographically close firms can cooperate. Increased competition arises because proximate competitors focus on each other to a greater extent than distant firms [13]. According to Porter, competition and cooperation can coexist because they occur in different dimensions and between different players [14].

Simmie points out a main feature of Porter's concept that distinguishes clusters from other types of agglomeration economies and may account for its popularity and that is the fact that innovation in clusters mainly results from or is driven by severe national or regional competition, 'competitiveness' being a determinant notion in this approach [14]. Competition develops between firms linked in vertical (buying-selling relationships) or horizontal (complementary products and services) clusters [15]. This increased importance granted to competition highlights the role of innovation and efficiency in firm and regional competitiveness, resulting from strategic close links with buyers, suppliers and other institutions. Conversely, the previous models are less concerned with performance, productivity and competitiveness as core issues. Instead, they focus on learning, knowledge and in explaining innovation as fundamental determinants for achieving high performance, productivity levels and competitive positions. On the contrary, in clusters, innovation is more a means to an end, an input to success and competitiveness, while in the former models it is an output, a successful result of regional development organisation forms, which explains the interest in understanding innovation processes.

Bearing this in mind, one may find it useful to distinguish clusters from some related, although different territorial model concepts. Enright [16] provides a useful distinction:

- Industrial cluster: a set of industries related through buyer-supplier relationships or by common technologies, buyers, distribution channels or labour pools. Geographical scale is not involved. Similar to Porter's definition;

- Regional cluster: an industrial cluster whose members are located in close geographical proximity;

- Industrial district: concentration of firms involved in interdependent production processes within the same industry or industry segments that are embedded in a local community. Geographical delimitation often corresponds to daily travel to work distances;

- Innovative milieu: it comprises intensive linkages between organisations, especially in what concerns knowledge creation. Terms like innovation systems, learning regions and knowledge-based clusters are frequently used in similar contexts;

- Business networks: firms with ongoing interaction and a certain level of independence, but which do not need to operate in related industries nor be geographically concentrated.

Clusters and Industrial districts have many features in common, namely the interdependence between businesses that compete and cooperate, the interaction with a community and a supportive policy. However, clusters go deeper in acknowledging private sector leadership, a broader involvement of participants, stronger institutional support, attention to social structure and personal relationships, as well as the relevance of product lifecycles [17].

Besides this 'overuse' of the concept, there are several definitions of clusters. Although Porter's appears to be the most influential in the academic field and among policy makers, OECD has come up with a more recent conception that is widely diffused in the academic sphere [18, 19]: "Clusters are characterised as networks of production of strongly interdependent firms (including specialised suppliers), knowledge producing agents (universities, research institutes, engineering compa- 
nies), bridging institutions (brokers, consultants) and customers, linked to each other in a value adding producing chain" [18: 5].

This definition goes further into the analysis of innovative clusters, as groups of innovative firms that develop around knowledge creation and sharing of infrastructures, as well as highly concentrated and effective links between firms, investors and researchers. This approach to innovation clusters is very similar to the one adopted by the European Commission [20].

Porter argues that externalities which support competitiveness are developed at the spatial clusters level rather than at the wider and encompassing regional level. Regional success results, then, from the performance of specific networks and industrial configurations [21]. However, clusters were more recently reinterpreted by other academics, such as Enright [13, 16, 22], Cooke [23] and Rosenfeld [24] towards the inclusion of a wider environment that comprises universities, associations, research centres, etc., and embrace different types of collaboration relationships [11]. These new approaches are closer to innovation systems and learning regions conceptions, as they consider features like learning abilities, skills and competences and related interactions leading to innovation. For instance, tourism clusters are moving towards the inclusion of not only business firms or organisations, but also research institutions, training, support services or agencies, community, government, residents and other agencies [17].

A second limitation refers to the fact that the concept is 'elastic' enough to prevent the development of a universal model of how agglomeration relates to regional economic growth and it is applied so widely that its explanation of causality and determination is overly stretched, thin and fractured [12].

Despite the many studies and definitions developed over the years, clusters remain a fuzzy concept used interchangeably to define an agglomeration of business. However, they can be classified according to different criteria. For instance, Enright [22] distinguishes clusters according to their stage of development. They can be potential, latent or working clusters, depending on the number of firms (critical mass) and key elements, such as the level of interaction, cooperation, competition, synergies, trust, self-awareness, etc. They can also be policy driven clusters (chosen by governments for support but lack a critical mass of firms or suitable conditions for development) and "Wishful thinking" clusters (policy driven clusters that, besides lacking critical mass, do not possess any source of advantage for promoting development).

According to Kettels [25], clusters may also be classified by the type of product or services provided, their specialisation in a stage of the value chain, their geographical focus, their ability to target a specific market segment or by the locational dynamics in which local industry cluster serves only local markets and their dependence on natural resources (as is the case of most tourism destinations and products). In addition, there are also traded industry clusters that are free to choose their location according to the quality of the business environment.

The significance of space and location arises from the acknowledgement that local factors of production are used in particular places and innovation is the result of how these factors are utilised, combined and upgraded in those specific localities [26].

Traditional approaches to the creation of clusters took into consideration two different types: horizontal or vertical clustering. Horizontal clustering, the most usual, occurs when firms in the same stage of the value chain for the same industry co-locate geographically. The firms are direct competitors, as they sell the same products and mobilise the same resources (e.g. cluster of hotels or museums). Its advantages derive from expanding potential customers to increase sales, shared information, shared infrastructure, reduction of costs, positive externalities. Vertical clustering takes place when firms operating at different stages of supply chain co-locate. It minimises logistics and distribution costs and concentrates labour supply, workforce skills and market information [27]. Despite the importance of the mentioned clustering types, Michael [27] expands the categories to include diagonal clustering, arguing that it has increased relevance for the tourism industry and destinations. It refers to a concentration of complementary firms, where each adds value to the activities of others even if the products they offer are distinct and belong to other industries.

\section{Objectives and methodology}

\subsection{Objectives}

The purpose of this article is to provide a map of the Portuguese territory, presenting NUTs III grouped in clusters so as to show what unites and separates them, both in terms of the location of production activities and other economic variables. This picture of the territory was pieced together taking 2010 as the reference year, except about one of the variables as shown below. 
Knowing the Portuguese territory so that better strategic development policies may be outlined is, then, the main goal of this analysis.

\subsection{Brief characterisation of the variables}

\subsubsection{Location Quotients}

The question of how production activities are distributed within a given space, showing a tendency to concentrate in certain places or rather to disperse themselves is particularly relevant for the economic and social analysis of a territory and instrumental in designing adequate regional development policies.

Location Indicators are often used; in this particular case, they served to determine the Location Quotient based on data from employment sectoral distribution, taking 2010 as the reference year. The data were obtained from the Instituto Nacional de Estatística (INE) ${ }^{1}$ [28].

\section{Location Quotient}

This indicator $(L Q)$ is a location measure in the sense that it allows us to assess the relative concentration degree of a given activity $(k)$ in a given region (i). Analytically $L Q_{i k}=\left(x_{i k} / x_{i}\right) /\left(x_{k} / x\right)$, where the numerator measures the concentration of the gross value added of region $i$ in sector $\mathrm{k}$ and the denominator measures the concentration of the reference region's gross value added in sector $k$. The reference basis is the unit. Thus:

$L Q_{i k}<1-$ means that sector $k$ in region $i$ is not very significant, and that the region is not particularly specialized in sector $k$;

$L Q_{i k}=1-$ in this case, the relative importance of sector $k$ in region $i$ equals its importance in the reference region;

$L Q_{i k}>1-$ means that sector $k$ in region $i$ plays an important role, and that the region is relatively specialized in sector $k$.

Location quotients are useful tools to characterize regions internally and to compare them both among themselves and with the reference territorial unit. Additionally, the analysis of their evolution in time, namely using descriptive statistical measures, allows us to approach the regions' internal dynamics as well as their inter-relationships [29].

\subsubsection{Other variables}

Besides sectoral production Location Quotients, the following variables were also used:

- Purchasing Power Indicator per Capita (PPIpC) - this indicator, supplied by INE [30], shows the daily purchasing power indicator per capita, in various municipalities or regions, taking the national value as a reference (Portugal $=100$ ). It is calculated through a specific factor analysis

\footnotetext{
${ }^{1}$ Portuguese National Statistics Institute.
}

model, based on several variables ${ }^{2}$, that makes it possible to address the various dimensions of the phenomenon. In this study, the factor analysis model referred to 2011, the year closest to the period under analysis.

- Competitiveness Index - it is part of the Regional Development Composite Index (ISDR) which was constructed by the Portuguese National Statistics Institute together with the Department of Forecasting and Planning and International Relationships (DPP) of the Ministry for Environmental Affairs, Land Use Planning and Regional Development. As its name suggests, this indicator measures a territory's capacity to compete. According to INE [31], a territory is considered competitive when it can beat its competitors in the international market as regards trade and attraction of investment, skilled human resources and visitors. Therefore, a number of indicators were selected ${ }^{3}$ to allow the construction of this index. The data used refer to 2010 and were gathered from INE [32].

- Environmental Quality Index - Likewise, the Environmental Quality Index is also part of the ISDR calculated by INE [31] and the data refer to 2010 [32]. The Environmental Quality Index ${ }^{4}$

2 The purchasing power indicator per capita is obtained from the following variables: Paid Personal Income Tax, Disclosed Gross Income for Tax Purposes (RDECLIRS); Value of Payment Operations through ATMs (VOPRPAG); Value of National Purchases through Automatic Payment Terminals (COMTPNAC); Value of Domestic ATM Cash Withdrawals (LEVMULN); Granted Housing Credit (CREHABT); Number of Passenger Cars Sold (AUTOMOV); Employees' Monthly Income (GANHTCO); Road Tax (IUC); Population residing in places with over 5,000 inhabitants in proportion to Total Residing Population (TXURB5); Turnover of Enterprises within division 47 of NACE-Rev.3 (VVNECOM); Value of International ATM Cash Withdrawals (LEVMULINT); Value of International Purchases through Automatic Payment Terminals (COMTPINT); Turnover of Enterprises within division 55 of NACE-Rev.3 (VVNEALOJ); Value of Urban Property Purchase and Sale Agreement (TPRURB); Municipal Tax on Real Estate Transfer (IMT); Real Estate Municipal Tax (IMI). Variables relativised by the residing population were calculated by using INE's estimation of the residing population on December 31st, 2011 [30].

${ }^{3}$ In order to measure competitiveness, some indicators were chosen that would allow us to ascertain such aspects as the capacity to generate income or gain access to external markets; the potential of competitiveness inducing factors like human resources advanced infrastructures and agglomeration economies, regional economies' likely development and population's, workers' and firms' regional attractiveness [31].

${ }^{4}$ In what concerns environmental quality indicators, the INE [31] has chosen those which indicate: the quality of the environment in terms of both drinking water and air; soil, water and air polluting factors; the quality of urban growth; measures to alleviate stress factors' impact, such as soil and water pollut- 
was included due to the importance of the sustainable development concept in which the environment plays a major role together with economy and society. The United Nations Report that was presented in 1987 and became known as the "Brundtland Report" defines sustainable development as "development that meets the needs of the present without compromising the ability of future generations to meet their own needs" [33: 37]. In a process in which it is expected that economic and urban growth repercussions on the environment be more and more controlled and environmentally sustainable practices promoting the efficient use of resources and reducing pressure on environmental systems be put in place, it is not possible to address development without taking into consideration environmental issues [31].

- Productivity - Values regarding productivity were obtained from INE [28] by calculating the total Gross Value Added (GVA) and Employment ratio for each region for 2010.

\subsection{Methodology for cluster construction}

In order to do an exploratory analysis of how the various variables relate to each other, we sought to group regions by building clusters. As described by Lypez [34: 441] it is a multivariate statistical method whose main purpose is ${ }^{1 ~}$ “... revelar concentraciones en los datos para su agrupamiento eficiente en clusters (o conglomerados) segъn su homogeneidad".

To build the above mentioned clusters, we followed the procedures suggested by Maroco [35], Pestana and Gageiro [36], Lypez [34] and SequeiraRamos [37]. Therefore, we initially sought to gather hierarchical clusters, using a methodology which consists of successive steps during which the individuals - in this case the concelhos ${ }^{2}-$ are first considered individually to be then grouped according to their proximity, or, conversely, to be included in a single cluster and later divided into sub-groups according to distance [35].

After several constructions had been tested with recourse to SPSS software, we obtained a set of variables of which the Purchasing Power Indicator per Capita, the Competitiveness Index, the Environmental Quality Index and Productivity scored the best results in building regional clus-

\footnotetext{
ing elements; the creation of classified zones serving as natura and ecological reservations as well as regional contributions to both replace fossil fuels by renewable resources or sources producing fewer greenhouse gas emissions and to use natural resources more rationally.

${ }^{1}$ To reveal concentrations of data and effectively gather them in clusters (or conglomerates) according to their homogeneity. (authors' own translation).

${ }^{2}$ Portuguese administrative territorial unit.
}

ters as regards location quotients of sectors $1,4,5$, 6,7 and $8^{3}$. Given that we were working with variables presenting different measurement scales, we proceeded to standardize them.

According to Pestana and Gajeiro [36] and Maroco [35], several cluster building methods must be tested in order to assess the similarity of results, as it happened with Complete Linkage and Average (between groups) methods. When one uses the non-hierarchic $K$-means, one verifies that the greatest similarity of results between this method and the hierarchic ones mentioned before is obtained via Average Linkage method. For this reason, we will use this method to ascertain the number of clusters using the criterion of the distance between clusters and the $R$-squared criteria.

After having drawn the distance graph (see annex), we verified we could retain 3 or 6 clusters; these options complemented by the $R$-squared criterion allow us to conclude the 6 cluster solution is the best, for the other alternative, the 3 cluster solution, retains a very low percentage of the total variability, whereas the former retains $84.52 \%$. This way, the analysis will be based on 6 clusters and following the $K$-means method, since according to various authors, namely Maroco [35], the probability of one doing a wrong classification of a certain subject in a given cluster is lower when one uses non-hierarchical methods.

\section{Result analysis}

\subsection{Result analysis regarding production lo- cation in NUTS III}

Looking at the production specialization of the various Portuguese NUTS III by economic activity sector in 2010 and based on the Location Quotient already presented, we will now rank how strongly that specialisation occurs in Portugal as a whole.

Beginning with agriculture, animal production, hunting, forestry and fishery, with a location quotient higher than one and lower than two, corresponding to a specialisation level that is less than twice as high as the country's taken as a whole, we have the following NUTS III: Minho-Lima, Baixo Mondego, Pinhal Litoral, Médio Tejo, Alentejo Litoral, Alto Alentejo and Baixo Alentejo.

A specialisation was corresponding to more than twice as high as that occurring in Portugal but not three times as high can be found in Baixo Vouga, Pinhal Interior Norte, Dão-Lafões, Serra da Estrela and Oeste. In Douro, Alto Trás-os-Montes, Pinhal Interior Sul, Beira Interior Norte and Beira

\footnotetext{
${ }^{3}$ It was not possible to use disaggregation by location quotients for the whole 10 sectors, having sectors $2,3,9$ and 10 been excluded.
} 

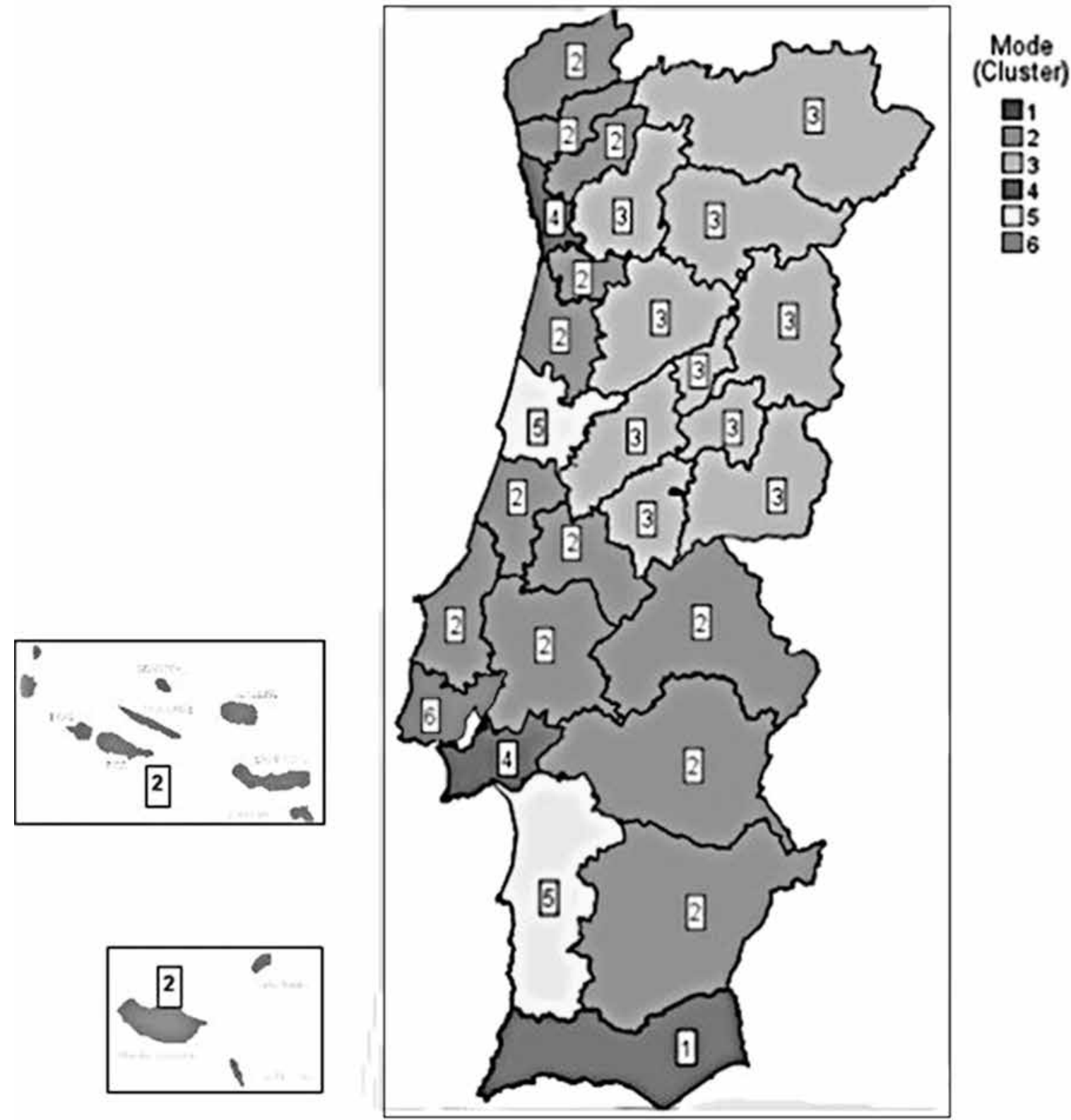

Source: authors' own calculations

Fig. 1. Portuguese NUT III regions organised in clusters

Interior Sul and Cova da Beira there is a productive specialisation that is more than three times as high as the one occurring in Portugal. It should be noted that in Alto Trás-os-Montes specialisation is higher than 4 and that the hinterland is essentially rural.

As to mining and quarrying, manufacturing, electricity, gas, steam and air conditioning supply, water supply, sewerage, waste management and depollution, the NUTS III with the highest level of specialization are Ave, Tâmega and Entre Douro and Vouga, all in the North, but their Location Quotient is little over 2.5. Minho-Lima Cávado,
Grande Porto, Baixo Vouga, Pinhal Litoral, Pinhal Interior Norte, Médio Tejo and Baixo Alentejo exhibit a productive specialisation that does not exceed the double of the one verified for the country as regards this activity sector.

In the construction sector, there is productive specialisation in 17 of the 30 NUTS III, but its Location Quotient is always lower than 2.

Wholesale and retail trade, repair of motor vehicles and motorcycles, transportation and storage, accommodation and food service activities are relevant in Lisboa and Porto as well as in the Algarve and Madeira; however, the Location 
Quotient is barely over one and a half times higher than the country's.

The information and communication sector as well as financial activities and insurance have their greatest impact in Grande Porto and Grande Lisboa, especially in the latter, where information and communication reach a Location Quotient a little higher than 2.6.

Real estate activities are also important in Grande Lisboa and Grande Porto, but their greatest impact is felt in the Algarve.

Once again, Grande Porto and Grande Lisboa are the most specialised NUTS III in such sectors as professional, scientific and technical activities and administrative and support service activities.

Other sectors like public administration and defence, compulsory social security, education, health care and social welfare, artistic and entertainment activities, repair of personal and household goods and other services are more present in 11 of the 30 NUTS III, where there is almost a spatial coincidence of the productive spatialisation.

\subsection{Clusters}

Figure 1 presents the geographical distribution of the clusters obtained through the $K$-means method and table I shows the composition of each cluster. Descriptive statistics of standard variables can be found in table II. The remaining relevant outputs of the process are also enclosed.

In geographical terms, cluster 1 includes the southern region, the Algarve; cluster 2 Alentejo and some parts of the coastline; cluster 3 all of the northern and central hinterland; cluster 4 Grande Porto and Península de Setúbal; cluster 5 the coastline of Baixo Mondego and Alentejo; and finally, cluster 6 Grande Lisboa (table I).

The descriptive statistics of each cluster can be seen in table II.

Enclosed is the variance analysis which allows us to identify which variables lead to cluster distribution and their relative importance. Looking at the table, we verify that the variables which contribute most to differentiation are Location Quotient in sectors 8, 7, 5 and 6 and Purchasing Power Indicator per capita, followed by Location Quotient in sectors 4 and 1, Competitiveness Indicator, Productivity and finally the Environmental Indicator.

Thus, cross-referencing information of the statistics table, the following characteristics stand out:

- Cluster 1 (South): the focus is on the location of real estate activities (sector 7 ) and on sector 4 - wholesale and retail trade, repair of motor vehicles and motorcycles, transportation and storage, accommodation and food service activities.
Table I

\begin{tabular}{|c|c|l|}
\multicolumn{4}{|c}{ Distribution of NUT III by clusters } \\
\hline Cluster & N & \multicolumn{1}{|c|}{ NUT III } \\
\hline 1 & 1 & Algarve \\
\hline 2 & 14 & $\begin{array}{l}\text { Minho-Lima; Cávado; Ave; Entre Douro } \\
\text { e Vouga; Baixo Vouga; Pinhal Litoral; } \\
\text { Oeste; Médio Tejo; Alto Alentejo; Alentejo } \\
\text { Central; Baixo Alentejo; Lezíria do Tejo; } \\
\text { Azores; Madeira }\end{array}$ \\
\hline 3 & 10 & $\begin{array}{l}\text { Tâmega; Douro; Alto Trás-os-Montes; } \\
\text { Interior Sul; Serra da Estrela; Beira } \\
\text { Interior Norte; Beira Interior Sul; Cova da } \\
\text { Beira }\end{array}$ \\
\hline 4 & 2 & Grande Porto; Península de Setúbal \\
\hline 5 & 2 & Baixo Mondego; Alentejo Litoral \\
\hline 6 & 1 & Grande Lisboa \\
\hline
\end{tabular}

Source: authors' own calculations.

- Cluster 2 (Coastline, Alentejo; The Azores and Madeira) - weak location of professional, scientific and technical activities (sector 8), of the information and communication sector and financial activities and insurance (sectors 5 and 6) as well as of the level of Purchasing Power per capita and of Competitiveness, although not so weak as in cluster 3.

- Cluster 3 (Northern and central hinterland) - The emphasis is on the concentration of sector 1 activities- agriculture, animal production, hunting, forestry and fisheries and its relevant positioning in terms of the Environmental Indicator. It has, however, a weak concentration of consulting, scientific and technical activities (sector 8) and of information, communication, financial and insurance activities (sectors 5 and 6). Purchasing Power per capita together with Competitiveness show the lowest average value of all the clusters.

- Cluster 4 (Porto and Setúbal) - it shows a relative concentration of information, communication, financial and insurance activities (sectors 5 and 6) and considerable average values of Purchasing Power per capita and of sector 4 activities - wholesale and retail trade, repair of motor vehicles and motorcycles, transportation and storage, accommodation and food service activities. Competitiveness is relevant in this cluster, although not so relevant as in Grande Lisboa.

- Cluster 5 (Central Portugal and Alentejo Coastline) - This cluster distinguishes itself from the others by its value as regards productivity which is only slightly excelled by Grande Lisboa, although its performance is not so good when it comes to environmental quality.

- Cluster 6 (Grande Lisboa) - strong location of consulting, scientific, technical, adminis- 
Table II

Summary of variable descriptive statistics by clusters

\begin{tabular}{|c|c|c|c|c|c|}
\hline Variable & Cluster & $\mathbf{N}$ & Mean & Minimum & Maximum \\
\hline Zscore: Development Index Environmental Quality (2010) & 1 & 1 & -0.59 & -0.59 & -0.59 \\
\hline Zscore: Productivity (2010) & 1 & 1 & 0.67 & 0.67 & 0.67 \\
\hline Zscore: Location Quotient Employment Sector 1 (2010) & 1 & 1 & -1.01 & -1.01 & -1.01 \\
\hline Zscore: Location Quotient Employment Sector 4 (2010) & 1 & 1 & 2.83 & 2.83 & 2.83 \\
\hline Zscore: Location Quotient Employment Sector 5 (2010) & 1 & 1 & -0.09 & -0.09 & -0.09 \\
\hline Zscore: Location Quotient Employment Sector 6 (2010) & 1 & 1 & 0.20 & 0.20 & 0.20 \\
\hline Zscore: Location Quotient Employment Sector 7 (2010) & 1 & 1 & 4.32 & 4.32 & 4.32 \\
\hline Zscore: Location Quotient Employment Sector 8 (2010) & 1 & 1 & 0.80 & 0.80 & 0.80 \\
\hline Zscore: Purchasing Power per capita (2011) & 1 & 1 & 0.69 & 0.69 & 0.69 \\
\hline Zscore: Development Index Competitiveness (2010) & 1 & 1 & 0.60 & 0.60 & 0.60 \\
\hline Zscore: Development Index Environmental Quality (2010) & 2 & 14 & -0.03 & -1.09 & 1.54 \\
\hline Zscore: Productivity (2010) & 2 & 14 & 0.19 & -0.44 & 1.62 \\
\hline Zscore: Location Quotient Employment Sector 1 (2010) & 2 & 14 & -0.43 & -0.98 & 0.31 \\
\hline Zscore: Location Quotient Employment Sector 4 (2010) & 2 & 14 & 0.24 & -0.70 & 1.66 \\
\hline Zscore: Location Quotient Employment Sector 5 (2010) & 2 & 14 & -0.11 & -0.46 & 0.45 \\
\hline Zscore: Location Quotient Employment Sector 6 (2010) & 2 & 14 & -0.06 & -0.56 & 0.49 \\
\hline Zscore: Location Quotient Employment Sector 7 (2010) & 2 & 14 & -0.06 & -0.62 & 0.76 \\
\hline Zscore: Location Quotient Employment Sector 8 (2010) & 2 & 14 & -0.03 & -0.55 & 0.60 \\
\hline Zscore: Purchasing Power per capita (2011) & 2 & 14 & -0.02 & -0.57 & 0.53 \\
\hline Zscore: Development Index Competitiveness (2010) & 2 & 14 & 0.12 & -0.95 & 1.26 \\
\hline Zscore: Development Index Environmental Quality (2010) & 3 & 10 & 0.75 & -0.35 & 1.99 \\
\hline Zscore: Productivity (2010) & 3 & 10 & -0.96 & -1.25 & -0.72 \\
\hline Zscore: Location Quotient Employment Sector 1 (2010) & 3 & 10 & 1.13 & -0.62 & 1.90 \\
\hline Zscore: Location Quotient Employment Sector 4 (2010) & 3 & 10 & -1.01 & -1.43 & -0.62 \\
\hline Zscore: Location Quotient Employment Sector 5 (2010) & 3 & 10 & -0.54 & -0.73 & -0.30 \\
\hline Zscore: Location Quotient Employment Sector 6 (2010) & 3 & 10 & -0.55 & -0.85 & -0.19 \\
\hline Zscore: Location Quotient Employment Sector 7 (2010) & 3 & 10 & -0.66 & -0.97 & -0.01 \\
\hline Zscore: Location Quotient Employment Sector 8 (2010) & 3 & 10 & -0.74 & -0.96 & -0.52 \\
\hline Zscore: Purchasing Power per capita (2011) & 3 & 10 & -0.82 & -1.43 & 0.04 \\
\hline Zscore: Development Index Competitiveness (2010) & 3 & 10 & -0.82 & -1.87 & -0.11 \\
\hline Zscore: Development Index Environmental Quality (2010) & 4 & 2 & -1.48 & -1.65 & -1.32 \\
\hline Zscore: Productivity (2010) & 4 & 2 & 0.72 & 0.72 & 0.72 \\
\hline Zscore: Location Quotient Employment Sector 1 (2010) & 4 & 2 & -1.25 & -1.27 & -1.22 \\
\hline Zscore: Location Quotient Employment Sector 4 (2010) & 4 & 2 & 1.10 & 0.88 & 1.31 \\
\hline Zscore: Location Quotient Employment Sector 5 (2010) & 4 & 2 & 1.17 & 0.68 & 1.67 \\
\hline Zscore: Location Quotient Employment Sector 6 (2010) & 4 & 2 & 0.93 & -0.01 & 1.86 \\
\hline Zscore: Location Quotient Employment Sector 7 (2010) & 4 & 2 & 0.89 & 0.82 & 0.95 \\
\hline Zscore: Location Quotient Employment Sector 8 (2010) & 4 & 2 & 1.62 & 0.87 & 2.37 \\
\hline Zscore: Purchasing Power per capita (2011) & 4 & 2 & 1.31 & 0.98 & 1.65 \\
\hline Zscore: Development Index Competitiveness (2010) & 4 & 2 & 1.04 & 0.67 & 1.40 \\
\hline Zscore: Development Index Environmental Quality (2010) & 5 & 2 & -1.84 & -1.92 & -1.76 \\
\hline Zscore: Productivity (2010) & 5 & 2 & 1.63 & 0.27 & 2.99 \\
\hline Zscore: Location Quotient Employment Sector 1 (2010) & 5 & 2 & -0.17 & -0.23 & -0.10 \\
\hline Zscore: Location Quotient Employment Sector 4 (2010) & 5 & 2 & 0.37 & 0.04 & 0.70 \\
\hline Zscore: Location Quotient Employment Sector 5 (2010) & 5 & 2 & 0.11 & -0.52 & 0.74 \\
\hline Zscore: Location Quotient Employment Sector 6 (2010) & 5 & 2 & -0.08 & -0.22 & 0.06 \\
\hline Zscore: Location Quotient Employment Sector 7 (2010) & 5 & 2 & 0.02 & -0.29 & 0.34 \\
\hline Zscore: Location Quotient Employment Sector 8 (2010) & 5 & 2 & -0.03 & -0.24 & 0.17 \\
\hline Zscore: Purchasing Power per capita (2011) & 5 & 2 & 0.76 & 0.44 & 1.09 \\
\hline
\end{tabular}


Table II end

\begin{tabular}{|l|c|c|c|c|c|}
\hline \multicolumn{1}{|c|}{ Variable } & Cluster & N & Mean & Minimum & Maximum \\
\hline Zscore: Development Index Competitiveness (2010) & 5 & 2 & 0.32 & 0.20 & 0.44 \\
\hline Zscore: Development Index Environmental Quality (2010) & 6 & 1 & 0.12 & 0.12 & 0.12 \\
\hline Zscore: Productivity (2010) & 6 & 1 & 1.67 & 1.67 & 1.67 \\
\hline Zscore: Location Quotient Employment Sector 1 (2010) & 6 & 1 & -1.35 & -1.35 & -1.35 \\
\hline Zscore: Location Quotient Employment Sector 4 (2010) & 6 & 1 & 1.01 & 1.01 & 1.01 \\
\hline Zscore: Location Quotient Employment Sector 5 (2010) & 6 & 1 & 4.50 & 4.50 & 4.50 \\
\hline Zscore: Location Quotient Employment Sector 6 (2010) & 6 & 1 & 4.55 & 4.55 & 4.55 \\
\hline Zscore: Location Quotient Employment Sector 7 (2010) & 6 & 1 & 1.27 & 1.27 & 1.27 \\
\hline Zscore: Location Quotient Employment Sector 8 (2010) & 6 & 1 & 3.86 & 3.86 & 3.86 \\
\hline Zscore: Purchasing Power per capita (2011) & 6 & 1 & 3.69 & 3.69 & 3.69 \\
\hline Zscore: Development Index Competitiveness (2010) & 6 & 1 & 3.28 & 3.28 & 3.28 \\
\hline
\end{tabular}

Source: authors' own calculations.

trative and service activities (sector 8) real estate activities (sector 7) and of information, communication, financial and insurance activities (sectors 5 and 6). Purchasing Power per capita shows the highest values; sector $4-$ wholesale and retail trade, repair of motor vehicles and motorcycles, transportation and storage, accommodation and food service activities - plays a major role. It is also best positioned as regards Competitiveness and Productivity.

\section{Final considerations}

Cluster analysis allowed us to confirm that in 2010 the country revealed deep asymmetries. First there was a coastline/hinterland dichotomy with the former taking the lead in terms of tertiary sector activities, from trade, transportation and storage, accommodation and food service activities to information, communication, financial, insurance, real estate, consulting and technical activities. This region is also best positioned in terms of Purchasing Power, Competitiveness and Productivity. Moreover, there is a north/south dichotomy with the former, particularly the hinterland, being the region where primary sector activities like agriculture, animal production, hunt- ing, forestry and fishery carry a big weight, besides being well positioned as refers to environmental indicators. Purchasing Power, Productivity and Competitiveness are weak, however.

In other words, almost thirty years after having joined the European Union and having been the recipient of financial aid packages, asymmetries still persist and the hinterland, which has always been deemed a low-density region, is still poor.

Now that the analysis phase has been concluded, any future work regarding clusters will move on to a more micro level, namely at the level of the concelho, in order to detect specialization areas and/or productive location. In line with previous studies about clusters carried out in Portugal namely by Sequeira and Diniz [38], we will try and establish the relationship between customer and supplier, technological chain and other relationships within the clusters.

These data will be cross-referenced with recent EU support to the development of several regional productive clusters so as to contribute to the discussion of how these policies and their effectiveness, while regional development factors, can make a difference in accordance with the studies and theories mentioned in the introduction.

\section{References}

1. Akgüngör, S. \& Falcioğlu (2005). European Integration and Regional Specialization Patterns in Turkeys's Manufacturing Industry. Discussion Papers Series N 05-01 October 2005. Dokus Eykŭ University, Faculty of Business, Department of Economics.

2. Michaels, G. (2006). The long-term consequences of regional specialization, Centre of Economic Performance, Discussion Paper, 776, December, London School of Economics, London.

3. Ezcurra, R., Gil, C. \& Pascualy, P. (2004). Regional Specialization in the European Union D.T. 2004/04. Department of Economics Universidad Publica de Navarra.

4. Traistaru, I. \& Iara, A. (2002). Integration, Regional Specialization and Growth Differentials in EU Acceding Countries: Evidence from Hungary. European Regional Science Association in its series ERSA conference papers with number ersa04p298. Available at: http://www-sre.wu-wien.ac.at/ersa/ersaconfs/ersa04/PDF/298.pdf

5. Diniz, F. \& Sequeira, T. (2009). Productive specialization and regional development in Portugal at the NUTS III level. Romanian Journal of Regional Science, 3 (2), 90-111.

6. Desrochers, P. (2007). Human Creativity and the Case Against Regional Specialization: Theory, Case Studies and Policy Implication. Working paper of Institute for Policy Studies, Johns Hopkins University.

7. Marelli, E. (2004). Evolution of employment structures and regional specialisation in the EU. Economic Systems, $28,35-59$. 
8. Goschin, Z., Constantin, D. L., Roman, M. \& Bogdan, V. I. (2009). Specialization and Concentration patterns in the Romanian Economy. Journal of Applied Quantitative Methods, 4 (1), 95-111.4.

9. Clar, G., Sautter, B. \& Hafner-Zimmermann, S. (2008). Strategic Cluster Development: Applying Strategic Policy Intelligence to create a Joint Research Agenda. Background paper for the CReATE project. Available at: http://www.lets-create.eu/fileadmin/_create/downloads/del-1-2_cluster-background-paper_revised_final.pdf.

10. Moulaert, F. \& Sekia, F. (2003). Territorial Innovation Models: A Critical Survey. Regional Studies, 37 (3), $289-302$.

11. Lagendijk, A. (1997). Will New Regionalism survive? Tracing dominant concepts in economic geography EUNIT. Discussion Papers, 10. University of Newcastle upon Tyne: CURDS.

12. Martin, R. \& Sunley, P. (2003). Deconstructing clusters: chaotic concept or policy panacea? Journal of Economic Geography, $3(1), 5-35$

13. Enright, M. J. (2003). Regional Clusters and Firm Strategy. In A. D. Chandler, P. Hagstrom and Ö. Sölvell (eds.), The Dynamic Firm: The Role of Technology, Strategy, Organization, and Regions. Oxford: Oxford University Press.

14. Porter, M. E. (1998a). Clusters and the New Economics of Competition. Harvard Business Review, 76 (6), 77-90.

15. Simmie, J. (2004). Innovation and clustering in the globalised international economy. Urban Studies, 41 (5/6), 1095-1112.

16. Enright, M. J. (1996). Regional Clusters and Economic Development: A Research Agenda. In U. Staber, N. Schaefer and B. Sharma (eds.), Business Networks: Prospects for Regional Development. New York: De Gruyter, 190-214.

17. Jackson, J., \& Murphy, P. (2006). Clusters in regional tourism: An Australian case. Annals of Tourism Research, 33(4), $1018-1035$

18. OECD (1999). Boosting Innovation: The Cluster Approach. Paris: OECD.

19. OECD (2001). Innovative Clusters: Drivers of the National Innovation Systems. Paris: OECD.

20. European Commission (2008). The concept of Clusters and Cluster Policies and their role for Competitiveness and Innovation: Main statistical results and lessons learned. Luxembourg: Office for Official Publications of the European Communities.

21. Porter, M. E. (1996). Competitive advantage, agglomeration economies and regional policy. International Regional Science Review, 19 (1), 85-94.

22. Enright, M. J. (2001, 12-13 November). Regional clusters: what we know and what we should know. Paper presented at the Kiel Institute International Workshop on Innovation Clusters and Interregional Competition.

23. Cooke, P. (2001). Regional Innovation Systems, Clusters, and the Knowledge Economy. Industrial \& Corporate Change, 10 (4), 945-974.

24. Rosenfeld, S. A. (1997). Bringing business clusters into the mainstream of economic development. European Planning Studies, 5(1), 3.

25. Kettels, C. H. M. (2003). The development of Cluster concept - present experiences and further developments. Paper presented at the NRW conference on clusters, Duisburg, Germany, 5 Dec.

26. Porter, M. E. (2001). Innovation: Location Matters. MIT Sloan Management Review, 42 (4), 28-36.

27. Michael, E. J. (Ed.). (2007). Micro-clusters and Networks: The Growth of Tourism. Oxford: Elsevier.

28. INE (2013a). Information relativa a dados sobre Actividade Produtiva, em termos Emprego e VAB, prestada atravis do pedido N/ Refa: n. PED-152454536, em 2013.

29. Delgado, A. P \& Godinho, I. M. (2005) Medidas de localização das actividades e de especialização regional. In Compêndio de Economia Regional, 2 Edição, Jose Costa Coordenador APDR, Coimbra, 713-732.

30. INE (2013b). Estudo sobre o Poder de Compra Concelhio 2011. Editor Instituto Nacional de Estathstica, I. P. Lisboa. Portugal.

31. INE (2009). Índice Sintético de Desenvolvimento Regional. Instituto Nacional de Estatística, I. P. Lisboa. Portugal.

32. INE (2014a). Dados recolhidos relativos ao Índice sintŭtico de desenvolvimento regional (Competitividade e Qualidade Ambiental) por Localizazzo geográfica, relativos ao ano 2010. Acedido em www.ine.pt, em Junho de 2014.

33. United Nations (1987). Report of the World Commission on Environment and Development. Our Common Future. Available at: http://conspect.nl/pdf/Our_Common_Future-Brundtland_Report_1987.pdf, em Junho 2014.

34. Lopéz, César P. (2005). Métodos Estadísticos Avanzados com SPSS. Madrid: Thomson.

35. Maroco, João (2011). Análise Estatística com o SPSS Statistics. 5 Edição. Pero Pinheiro: Report Number.

36. Pestana, M. H.; Gageiro, J. N. (2008). Análise de dados para as Ciências Sociais. A complementaridade do SPSS. 5 Edição. Lisboa: Edições Sílabo.

37. Sequeira-Ramos, M. T. C. da C. (2006). Incentivos ao Investimento e Desenvolvimento Regional. Tese de Doutoramento. UTAD. Vila Real.

38. Sequeira, T. \& Diniz, F. (2009). Port wine cluster: old forces, new challenges. In Clusters. Politics Management. Good Clustering Practices in the world. Edited by Ewa Bojar, Poland, 261-277.

\section{Information about the authors}

Francisco José Lopes de souse Diniz (Vila Real, Portugal) - PhD in Economics, Dr., Associate Professor with Habilitation (Retired), Transdisciplinary Centre for Development Studies, University of Trás-os-Montes and Alto Douro (8, Bairro Souto Velho Lote, Vila Real, 5000-062 Portugal, email: fdiniz@utad.pt).

Maria Teresa Couceiro da Costa Sequeira e Sousa Carvalho (Vila Real, Portugal) - PhD in Economics, Dr., Assistant Professor, Transdisciplinary Centre for Development Studies, University of Trás-os-Montes and Alto Douro (8, Bairro Souto Velho Lote, Vila Real, 5000-062 Portugal, email: tsequeir@utad.pt). 